\title{
Greatness versus Smallness: A Postcolonial Analysis of the Healing of Naaman (2 Kings 5)
}

\author{
SIDNEY K. BERMAN (NWU, MAFIKENG CAMPUS)
}

\begin{abstract}
This article analyses the dichotomy of greatness versus smallness in $2 \mathrm{Kgs}$ 5. It argues that Naaman's real disease was an unhealthy attitude towards greatness, and Elisha primarily cured it. From the discourse of the story, Aram's and Naaman's looting and oppression of the weaker nation and individuals is borne from this disease. The investigation of this article is also postcolonial, drawing parallels between attitudes and power imbalances in the narrative and those of colonial relationships. The above-named concepts are merged with the method of literary narrative criticism to trace the text's reproof of imperialist ideology.
\end{abstract}

KEYWORDS: greatness; smallness; Naaman; colonial; Gehazi; Elisha.

\section{A INTRODUCTION}

This article presents an aesthetic postcolonial analysis of the story of the healing of Naaman in 2 Kgs 5. It traces the dichotomy of "greatness versus smallness" throughout the story. The article argues that the story of 2 Kgs 5 is primarily an admonition of an oppressive attitude towards greatness, which is embodied in the relationship of inequality between Israel and Aram. Because of Aram's military supremacy over Israel, Aram was the master while Israel was the servants. There are several factors in the story that could lead Naaman and the Arameans to regard themselves as superior to Israel. Similarly, there are some features of the story where the Israelites could consider themselves better than the Arameans. Yet the story eloquently and artistically works to rebuke that mentality. This article analyses the story's play on the concept of "greatness versus smallness" and argues that such a play can be used to reprimand imperialism. The article employs literary criticism to the narrative and applies a postcolonial mindset to narrative observations. The topics of the article are as follows: "historical setting and traditional interpretation," "postcolonial biblical interpretation," "narrative criticism and its implications," "a great man versus a small girl," "the small save the great," "Elisha's task," "equalising the relationship between Aram and Israel,” “Gehazi symbolically acquires Naaman’s

* Article submitted: 30/07/2016; article accepted: 28/09/2016. To cite: Sidney K. Berman, “Greatness versus Smallness: A Postcolonial Analysis of the Healing of Naaman (2 Kings 5),” OTE 29

(3) 2016: 403-418. Doi: http://dx.doi.org/10.17159/2312-3621/2016/v29n3a3. 
greatness," "a rebuke of colonial ideology" and "the correct attitude in the postcolonial era.”

\section{B HISTORICAL SETTING AND TRADITIONAL INTERPRETA- TION}

Studies on 2 Kgs 5 notes that at the time of the story, the relationship between Aram and Israel was one of inequality and oppression. Aram was militarily superior to Israel, although such superiority was not absolute. Aram was not powerful enough to rule over Israel. Hence Israel had its own sovereign king and was not a vassal or colony of Aram. This is perhaps why the text has not commonly been used to draw parallels with a colonial or imperialist mindset. Aram was victorious over Israel during many raids by small bands on the northern border of Israel, whereupon they would loot wealth and capture slaves. ${ }^{1}$ The Arameans would plunder and retreat before the Israelites could respond adequately. ${ }^{2}$ They captured the little maid during one of such raids. Because of these military victories, Aram assumed a position of greatness over Israel or, at least as observed from the narrative, exuded superiority in their encounters with Israel, and Israel was intimidated by Aram. The narrative utilises the character of Elisha the prophet to rebuke this kind of power imbalance.

Nothing in 2 Kgs 5 indicates a continuation of the story that precedes it or a link with the next narrative chronologically and content-wise. In other narratives, Naaman is never associated with leprosy, and Gehazi is never conniving or leprous. ${ }^{3}$ Moreover, 2 Kgs 5 is much longer and more complex than the short stories surrounding it, for it is a linking of three stories that end independently of each other. These are (i) the greatness of Elisha the prophet (vv. 114), (ii) the healing of Naaman the leper (vv. 15-19), and (iii) the disobedience and punishment of Gehazi (vv. 20-27). ${ }^{4}$

Interpreters of the text have generally praised Naaman's post-healing talk as a sign of genuine conversion and marvelous gratitude. ${ }^{5}$ They have tended to focus on missions and God's universal love. Furthermore, the irony that is often pointed out about God's plan is that the pagan can turn to God while an Israelite (Gehazi, for example) could fall from grace. The expositor's

1 Cf. 1 Sam 30:8; 2 Kgs 13:21; 2 Kgs 24:2. Karl F. Keil, “2 Kings,” in Commentary Critical and Explanatory on the Whole Bible, ed. Robert Jamieson, Andrew R. Fausset and David Brown (Grand Rapids, Michigan: Zondervan),

2 Frederic W. Farrar, "2 Kings," in The Expositor's Bible Commentary: With the New International Version, ed. Frank E. Gaebelein (Grand Rapids: Zondervan), http://biblehub.com/commentaries/expositors/2 kings/5.htm.

3 Robert L. Cohn, “Form and Perspective in 2 Kings V,”VT 33 (1983): 171.

4 Cf. Cohn, "Form and Perspective," 176.

5 Cf. Jean K. Kim, "Reading and Retelling Naaman’s Story (2 Kings 5),” JSOT 30 (2005): 52; Emmanuel O. Nwaoru, "The Story of Naaman (2 Kings 5:1-19): Implications for Mission Today,” SwMT 96 (2008): 27-41. 
Bible commentary, however, sees compromise in Naaman's plan to continue bowing down to Rimmon. ${ }^{6}$ Walter Brueggeman also sees insufficient gratitude and poor levels of commitment in Gehazi. ${ }^{7}$ The exposition in this article is similarly skeptical of Gehazi’s genuineness in gratitude and commitment.

\section{POSTCOLONIAL CRITICISM}

Postcolonialism is best summarised as a critical endeavor which seeks to expose and resist modern imperialism, imperial attitudes and theories and their continued incarnation in a wide panorama of fields such as politics, economics, history and theological and biblical studies. ${ }^{8}$ The mentality that gave rise to colonialisation in the past persists today in many educational systems, languages, literary canon and reading methods which the contemporary world has inherited. ${ }^{9}$ Following Elisha's rebuke and punishment of Gehazi, ${ }^{10}$ we realise that a colonial mindset can even be renewed and propagated by the formerly oppressed.

The narrative of 2 Kgs 5 lends itself to a postcolonial examination even though Aram and Israel were not in a colonial relationship. The relationship still embodies an imperial ideology that is preoccupied with greatness and smallness. Given the relevant context, this ideology divides reality between superior and inferior, master and slave, coloniser and colonised, male and female, black and white, reason and emotion, spirit and material and others. ${ }^{11}$ In this passage, the actions and attitudes of Aram mirror the characteristics of a coloniser while those of Israel parallel those of the colonised.

\section{NARRATIVE CRITICISM AND ITS IMPLICATIONS}

Narrative criticism is a literary method of interpreting narratives. In view of the traditional historical analysis of biblical texts, this approach is relatively new in biblical studies. It has resulted from the twentieth century's fascination with the Bible as literature with the same features as other literary works like poems, stories, letters and others. ${ }^{12}$ Whereas historical criticism focuses largely on the

6 Farrar, “2 Kings.”

7 Walter Brueggemann, "Perpetual Shalom: Elisha’s Gift to Naaman,” ChrCent (2012): 30-33.

8 Gosnell Yorke, Bible Translation in Anglophone Africa and Her Diaspora: A Postcolonial Agenda (London: Equinox Publishing Ltd, 2004), 158.

9 Kwok Pui-Lan, "Making the Connections: Postcolonial Studies and Feminist Biblical Interpretation,” in The Postcolonial Biblical Reader, ed. Sharada Sugirtharajah (Malden: Blackwell Publishing, 2006), 77-99.

10 See below, the section "A Rebuke of Colonial Ideology."

11 Brian Wren, What Language Shall I Borrow? God-talk in Worship: A Male Response to Feminist Theology (London: SCM Press, 1989).

12 David Jasper, "Literary Readings of the Bible," in The Cambridge Companion to Biblical Interpretation (Cambridge: University Press, 1998), 21. 
world of the historical author (the world behind the text), literary criticism strongly features the world of the text (the world as immediately observable from reading the text). According to Randolph Tate, reader-response criticism would be strongly skewed towards a third category, namely the world of the reader. ${ }^{13}$ Tate proposes a fourth context in hermeneutics, which is the merger of the three worlds in the process of finding meaning. Among these three worlds, this article uses narrative-literary criticism as its point of departure. In narrative criticism, the text has autonomous integrity "apart from circumstances relating to the historical reality behind the story." "This is more liberating to the reader than previously when historical criticism was the exclusive method of hermeneutics. The reader is much freer to apply the text to his/her own context. In the case of observable power imbalances between two nations in 2 Kgs 5, the narrative is immediately accessible to those who struggle with neocolonial inequalities and some people's obsession with superiority. According to the narrative, Aram would have a claim to national superiority over Israel for the following reasons: they have conquered Israel in raids, they can capture Israelite slaves, and the king of Israel is intimidated by his Aramean counterpart.

In the meaning-making process of narrative criticism, questions are asked on the level of characters (who?), settings (where and when?), events (what and why?), plot (their interaction) and the discourse (their rhetoric or way of persuasion). ${ }^{15}$ The primary characters of this narrative are Naaman, Elisha, and Gehazi. The minor ones are the little maidservant, the king of Aram, the king of Israel, Elisha's messenger and Naaman's attendants. Narrative characters and their actions serve to generate conflicts or tensions that create the plot of the story; ${ }^{16}$ this is unearthed from studying words, traits, actions, and narratorial comments. The relationships between the characters of 2 Kgs 5 are the embodiment of the conflict of the story, emanating from tensions between the great and the small. While the Arameans represent greatness, the Israelites, who represent smallness, work to reverse the situation and neutralise the relationship. ${ }^{17}$ Eventually, Naaman humbles himself before Elisha and Gehazi. Gehazi even goes further as he symbolically swaps places with Naaman.

13 Randolph W. Tate, Biblical Interpretation: An Integrated Approach, 3rd ed. (Grand Rapids, Mich.: Baker Academic, 2012).

14 Richard G. Bowman, "Narrative Criticism: Human Purpose in Conflict with Divine Presence," in Judges and Method: New Approaches in Biblical Studies, ed. Gale Yee (Minneapolis: Fortress Press, 1995), 17.

15 Mark A. Powell, "Literary and Structuralist/Postmodernist Approaches Methods," in Methods of Biblical interpretation, ed. Douglas Knight (Nashville: Abingdon, 2004), 170-171.

16 Richard G. Bowman, "Narrative Criticism: Human Purpose in Conflict with Divine Presence," in Judges and Method: New Approaches in Biblical Studies, ed. Gale Yee (Minneapolis: Fortress Press, 1995), 29.

17 Donald J. Wiseman, 1 and 2 Kings (Leicester: Inter Varsity Press, 1993), 206. 
Settings are spatial and temporal. ${ }^{18}$ The story reports events starting in Aram and ending in Israel at the time of Elisha's ministry. Scholars approximate that the events are set during the reigns of Ben Haddad II or III of Aram and Joram of Israel. ${ }^{19}$ The setting of 2 Kgs 5 is at the time when Aram, Israel's northern neighbour, enjoyed a certain level of military supremacy over Israel. ${ }^{20}$ The plot in narrative criticism is contained in some or all of the following elements: events; their causes; the technique used to present them; the conflict of right against wrong; changes of time, order, duration and others. ${ }^{21}$ The plot of 2 Kgs 5 is easy to follow because of the simplicity of its chronology and technique. Naaman's wife is advised by her servant girl, Naaman delivers a letter to the king of Israel, Elisha summons Naaman, Naaman goes through a humbling process, he is healed, Naaman is humble and grateful, Gehazi acquires riches from Naaman, and Gehazi acquires Naaman’s leprosy.

As for the discourse of 2 Kgs 5, this article discovered that the story condemns an obsession with greatness. Elisha believes that reveling in the dichotomy of "greatness versus smallness" is the cause of looting and oppressing innocent people. Obviously, it would work to Aram's advantage to nurture and expand such supremacy through more raids, which would weaken Israel and eventually render Aram's power over Israel absolute. The prophet Elisha seems to foresee such a development, and, in this narrative, works to curb it. Discourse indicates the rhetoric of the narrative or how the story aims for a persuasive effect. ${ }^{22}$ It is the point or theme of the story. The narrative is designed to persuade readers towards a certain viewpoint, sometimes referred to as the ideology of the text. The narrative of the healing of Naaman argues for the abandonment of a master/servant mentality.

\section{E A GREAT MAN VERSUS A SMALL GIRL}

2 Kings 5 begins by introducing to us a "great man” (איש גדול), Naaman. He is not just great because the king finds him likable, but because he is good at his job, being commander of the king's army (v. 1). The description continues to

18 Powell, "Literary and Stucturalist," 170.

19 Hermann J. Austel and Richard D. Patterson, "2 Kings,” in Old Testament, vol. 1 of Zondervan NIV Bible Commentary: An Abridgment of the Expository Bible Commentary, ed. Kenneth L. Barker and John R. Kohlenberger III (Grand Rapids, Michigan: Zondervan, 1994); Daniel S. Baeq, "Contextualizing Religious Form and Meaning: A Missiological Interpretation of Naaman's Petitions (2 Kings 5:15-19),” IJFM 27 (1983):198; Walter A. Maeir III, "The Healing of Naaman in Missiological Perspective," CTQ 61 (1997): 179.

20 Maeir III, “Healing of Naaman,” 178.

21 Powell, "Literary and Structuralist," 171.

22 Elizabeth S. Malbon, "Narrative Criticism: How Does the Story Mean?" in Mark and Method: New Approaches in Biblical Studies, ed. Janice C. Anderson and Stephen D. Moore (Minneapolis: Fortress Press, 1994), 26-27; Powell, "Literary and Structuralist,” 170-171. 
say that he was lifted up (of face, literally) by the king, which means he was generally an esteemed man. The man is great in position, honour and respect, and the king is happy to introduce him as "my official" in the letter to the Israelite king (v. 6). ${ }^{23}$ Naaman's record even speaks for him - he presided over Aram's conquest of Israel (v. 1). However, we immediately realise that there is something wrong with him - leprosy. From the story, it appears that leprosy in Syria is not as socially destructive to an individual as in Israel. ${ }^{24}$ Neither is Naaman's leprosy as incapacitating as our contemporary conception of leprosy would lead us to believe. ${ }^{25}$ As a successful commander and the king's right hand man, he certainly lives his life more triumphantly and publicly than most people. Although the descriptions change tone decisively, they are made in the same breath, as if leprosy is part and parcel of his greatness. In the rhetoric of the story, if Naaman is the embodiment of greatness, then his leprosy is a remonstration against the kind of greatness he embodies. Naaman is great because he is a murderer and looter of the weak, but he revels in it. Whereas that was normal for international relations during the time, it was wrong. Thus, according to the rhetoric of the story, Naaman's version of greatness should not be appraised separately from his sickness because it is unhealthy. Like Gehazi who symbolically gained Naaman's wealth, greatness and leprosy at the end of the story, the only way for Naaman to lose his leprosy is to lose this obsession with greatness.

From the letter to the king of Israel, it appears that the Arameans thought a miracle-working prophet would be known to the king, especially since he was known by even a little girl. ${ }^{26}$ Naaman's master knows that Naaman is going to see the prophet but he tells Naaman that he is sending a letter to the king of Israel (v. 5). It means the letter was a formality to pave the way to the prophet. As was the custom, the king of Aram communicated with the highest authority in the land. The mission was normally mentioned as a form of introduction, but its details would be explained during the discussion. Nevertheless, the king of Israel mistook it as a disguise to cause a conflict. ${ }^{27} \mathrm{He}$ was so intimidated that he could not think broadly. Elisha, however, had no respect for that system of inequality, so it did not intimidate him.

As for Naaman, when he goes to Israel, he expects to be recognised as the greatest there because he is the commander who conquers Israel in war. Symbolically, the great man of v. 1 (איש גדול) turned Israel into a little girl

23 Wiseman, 1 and 2 Kings, 206.

24 Cf. Karl F. Keil and Franz Delitzsch, 2 Kings, Biblical Commentary on the Old Testament ( $\mathrm{T} \& \mathrm{~T}$ Clark Edinburgh, 1857-1878), Online: http://biblehub.com /commentaries/kad/2_kings/5.html.

25 August H. Konkel, 1 \& 2 Kings (NIVAC; Grand Rapids, Mich.: Zondervan, 2006), 428-429; Kim, "Reading and Retelling,” 53.

26 Maeir III, “Healing of Naaman,” 179.

27 Wiseman, 1 and 2 Kings, 207. 
(the נערה קטנה of v. 2). They should recognise their master. A severe contrast stands out in respect to Naaman's greatness against his Israelite captive's smallness. Whilst his greatness is greatly amplified, the same is done with the description of the maid from Israel. The smallness is presented doubly by pairing the term נערה (young girl) with קטנה (small). Furthermore, the term that commonly denotes child is used for the maidservant instead of the more distinct term for slave/servant, namely עבדה (v. 4). Although both terms mean servant, נערה is used to stress the smallness of the Israelite captive. In reference to Naaman's servants, the word נער is discarded for עבד (v. 13). Great comes against small, Aramean against Israelite, conqueror against captive, male against female, adult against child, ruler against servant and famous against unnamed.

\section{F THE SMALL SAVE THE GREAT}

However, we find the smaller party breaking through the wall of differences. The small girl gives advice to her masters with the view to help them find healing -she encourages them to contact the prophet of the LORD in Israel who is able to cure Naaman's leprosy. Naaman's obsession with greatness has the effect of maintaining the dichotomies. He wants greatness to be maintained at personal and national levels. On a personal level, he expects the prophet Elisha to submit to him. On the national level, Naaman declares the superiority of the Syrian rivers over those of Israel (v. 12). He asks why he cannot wash in them because they are better. ${ }^{28}$ The great man protests the flagrant demolition of the wall of dichotomy between Aram and Israel. Naaman is preoccupied with greatness to the point of refusing to take a directive that would cure him. He storms away, and his servants reason with him, "If the prophet had told you to do something great (דבר גדול), it would be an easy task for you. But how about when he says wash and be clean?” They know that Naaman felt humiliated upon arrival and will be humiliated further by Elisha's method of healing. They also know that Naaman came expecting to partake in a spectacular act that would leave an audience in awe. ${ }^{29}$ Therefore, his servants assure him that they as the audience already know he is a great man who could never fail to perform a great act. This cleverly crafted short speech pacifies Naaman. It is noteworthy that in their speech about a great versus small act, the servants only mention the part about greatness and omit the one about smallness since something small (קטן) is indeed what their master should do. Instead they immediately state the act: "wash and be clean" as the contrast of "something great." They probably fear that he might disapprove of such belittling vocabulary, whereupon he might entirely refuse to wash. The great Naaman once again has to learn from servants as he did from the little maidservant. The irony is that in this story,

28 Musa Gotom, “1 and 2 Kings," in Africa Bible Commentary ed. Tokunboh Adeyemo (Grand Rapids, Mich.: Zondervan, 2006), 448.

29 Maeir III, “Healing of Naaman,” 181. 
wisdom does not emanate from the great but from the small. The smallest people play the greatest part for Naaman to find healing. ${ }^{30}$ Even the person who conveys to Naaman the directive that brought about his healing is a servant.

Elisha sent a servant to direct Naaman to proceed to the river Jordan to wash seven times (v. 10). He had expected the man of God to come out in person to him because he was Elisha's social superior. He was an army general - a great warrior - while Elisha was just a prophet. Moreover, he was a representative of a more powerful and thus greater nation than Elisha's. ${ }^{31}$ According to his own words, Naaman had thought that Elisha himself would make stunts in the process of curing him (v. 11). He surely associated himself with the great and spectacular. Instead, the prophet does not even lift a finger. More humiliatingly, Elisha suggests that he, Naaman, is in need of a bath. He considers him so dirty from his sick skin that even dirty water from the Jordan River will make him cleaner than he currently is. If Naaman were to agree to this humiliation and repeat it seven times, his ego would probably fail to recover.

\section{G ELISHA'S TASK}

Elisha's task is not to make Naaman know that there is a God in Israel. He declares: "Send him to me so that he will know that there is a prophet in Israel" (v. 8). Elisha might be powerless to make Naaman remember the LORD, or to forsake his gods whom he probably believes have outwitted the God of Israel. However, Elisha is convinced that Naaman will never forget meeting a prophet in Israel. Naaman can be imperial and exalt himself above everyone in the conquered nation, including even intimidating the king by his mere presence - but that will stop when he meets the prophet. From Naaman's arrival until his departure, Elisha ensures that this happens with the utmost impact. Therefore, Elisha becomes the primary character to rebuke an imperial mentality. We also begin to understand why the story linked Naaman's greatness to his leprosy and then to Elisha in v. 3: Elisha has begun to cure Naaman of the disease of greatness. If Naaman were to be cured of leprosy, he would have to start by being cured of his preoccupation with greatness.

When Naaman is cured, he declares that he now knows that there is no God apart from the God of Israel (v. 15). This acknowledgement is quite significant because Naaman has probably believed that his gods have conquered the God of Israel. Naaman uses a formula that foreigners sometimes used when the LORD had impacted on their lives, namely, "Now I know that ..." 32 However, Naaman does not finish his sentence. He continues with "and now ..." and introduces a different topic, namely to offer the prophet a gift. Then the full-stop comes (v. 15). He will probably bid farewell soon after the payment.

\footnotetext{
30 Kim, "Reading and Retelling," 52.

31 Konkel, 1 \& 2 Kings, 428.

32 Nwaoru, "Story of Naaman," 34.
} 
His first clause lacks the name of the God that he says is the only God on earth, even though we know that he calls gods by name - the Aramean god, Rimmon, for example. ${ }^{33}$ It is improbable that he does not know the name of the only God of the monotheistic nation, whose prophet is known even in Aram. Nonetheless, knowing that the Israelites believe that their God is the only God, he seems to have planned to recite their cliché. He would have done well to say, "And now I want to be told more about this God." Instead, it is clear that Naaman is not going to ask who this amazing God really is (vv. 15-16). Suddenly, a dilemma arises because the prophet refuses the payment despite his repeated pleas. On the one hand, it appears that Naaman fears to leave a debt behind. On the other hand, that is exactly what Elisha wants to happen. The reason could be that Elisha wants Naaman to feel indebted to God, which could eventually diminish if he pays the prophet. Conversely, he might want Naaman to feel indebted permanently in a way that dictates a change of lifestyle wherever he goes. A payment may not erase Naaman's sense of gratitude, but it could easily diminish his sense of commitment because as the story reveals, it will be quite difficult for him to live a life of commitment to the LORD.

Indeed, the plan of indebtedness is successful in as far as it leads Naaman to make lifestyle commitments. He offers to forsake his gods (whom Elisha probably regards as idols) and to serve the LORD only (v. 17). This would not be easy in Aram where there is no temple for the God of Israel, so Naaman will need some soil from Israel (v. 17). He will probably spread it as a base for his altar to compensate for the lack of a temple for the LORD. ${ }^{34}$ Naaman promises to no longer sacrifice to his gods. However, one might wonder why he would ask for soil from the prophet or even tell him. Soil is free, unguarded, has no owner, and for convenience could be collected nearer the border when Naaman is about to reach his home country. The most reasonable answer is that Naaman no longer feels comfortable to take anything in Elisha's country without asking, even if it is unguarded, free or has no owner. That change would be radical because as an army general, his main job is to enrich Aram; that is to take valuable items from their owners without asking, regardless of whether they are alive (people and livestock, for example) or are nonliving things (for example, money and minerals). What more about soil? Naaman's discomfort in acquiring Israelite items could actually cure him of raiding the northern border in the future, or at least reduce the raids. That could have been one of the effects that Elisha was aiming at, as far as changing Naaman's outlook was concerned.

As Naaman explains his need for the soil, he sounds as though he is intimidated by the prophet. He wants Elisha to know that he will still pay the LORD, so he begins to promise Elisha. In the polytheistic nation of Aram, the

33 Brueggemann, "Perpetual Shalom,” 30.

34 Wiseman, 1 and 2 Kings, 208. 
king would not object to the worship of the LORD. However, the king will not understand why Aramean gods have to be forsaken so that only the LORD is worshipped, as if the king's gods are inferior to the LORD. ${ }^{35}$ That will cause conflict. In his speech, he realises that Elisha would be naïve to believe this commitment at face value. Elisha knows that Naaman will return to his old life either by the momentum of routine or by his own volition. Thus, Naaman reduces his promise as follows: although he will worship God only, he will regularly accompany his master into a different god's temple, Rimmon's temple. Then what happens inside the temple? He cannot lie effectively because the prophet knows that indeed he will regularly bow down inside the temple. His explanation is that his bowing will be forced by his master's pull on his arm. However Naaman is probably thinking that Elisha can see through the childishness of this excuse, so, when he restarts his apology, he omits it. ${ }^{36}$ Thus, Naaman simply reports in his last sentence without citing any more excuses - he will indeed bow down to Rimmon (v. 18). For that act of unfaithfulness to the LORD, Naaman asks for forgiveness. Naaman is so intimidated by the prophet that his reasoning is incoherent; he makes an unsolicited commitment, reduces it, makes an excuse for reducing it, discards the excuse and finally admits that his promise will be difficult to fulfil. He will not bow down to the LORD only but will also bow down to Rimmon. After wishing for an audience with the great prophet, he fails to utilise the opportunity the way he had wanted.

The narrator's audience could be excused for lecturing to Naaman: "Choose for yourself today whom you will serve. If Rimmon is God, serve Rimmon. But if the LORD is God, serve the LORD." ${ }^{37}$ In any case, each time Naaman becomes insincere, he ends up deciding to be honest with the prophet. Naaman seems intimidated by the prophet's silence, especially since the prophet seems to see through to inner diseases of character. Elisha offers no suggestion or rebuke, but his only words are to wish Naaman peace. Elisha could tell Naaman that he is making a mistake because the LORD is greater than the Aramean god that he prefers. Nevertheless, Elisha avoids hinting at the comparison of greatness versus smallness of the deities of the two nations.

Elisha's passive reaction to Naaman's weak commitment and preference for Rimmon leads one to conclude that Elisha had never expected Naaman to change his religion or to make a lasting spiritual commitment. ${ }^{38}$ From that calmness it also appears that Elisha was satisfied that he had succeeded in what

35 Konkel, 1 \& 2 Kings, 433.

36 Sweeney adds that this would be when the king of Aram is weak with age, but this is only speculation. Cf. Marvin A. Sweeney, I \& II Kings: A Commentary (Louisville: Westminster John Knox Press, 2007), 300.

37 Cf. Brueggemann, "Perpetual Shalom," 32.

38 Baeq, "Contextualizing Religious Form,” 203-204. My arguments here are in line with Brueggemann’s perspective. 
he really wanted - to humble Naaman. While Naaman's change of religion and the extent of his gratitude might be unclear, there is clear evidence that Elisha had cured Naaman's leprosies of the body and of character. The clue to what Elisha wanted and achieved is stated in Elisha's own words: Naaman will know that there is a prophet in Israel (v. 8). However, it will be difficult for the narrator's audience to believe that Elisha could make himself the focus rather than make God the focus of the story. That presumption can make the audience easily miss Elisha's aim and achievement in the story. Naaman's preoccupation with greatness has been severely damaged by his encounter with the prophet. This prophet took control where the king failed and fearlessly summoned the great Naaman. ${ }^{39}$ From there he treated the general like a dirty leper. The prophet completely subdued Naaman and reduced him to the humility and likeness of a child. Naaman's commitment to the LORD might be weak and temporary, but the prophet is content. Naaman's humility is what he was looking for. As for the rest of Naaman's flaws, Elisha leaves them in the hands of the sovereign God who gave Naaman victory and cured him of leprosy.

\section{H EQUALISING THE RELATIONSHIP BETWEEN ARAM AND ISRAEL}

Elisha instructs Naaman to wash in the river Jordan seven times (v. 14). He chooses the number seven to signify fullness but also for practical purposes. It is unlikely that Naaman would keep dipping himself so repeatedly and still not be seriously humbled by the act and initiated into what Elisha had in mind. When he is through, his skin is as clean as a little boy's (נער קטן; v. 14). The irony is that Naaman becomes what the little girl was both in appearance and attitude. Not only does he look young and clean, but his attitude also changes as witnessed in his humility to Elisha and Gehazi (vv. 15 and 21). ${ }^{40}$ Like the at the beginning of the story, he takes the place of a little servant. He even calls himself Elisha's servant (v. 15). Since Naaman's flawed perception of greatness led to or contributed to Aramean raids on Israel, perhaps Israel will be saved from future raids by Aram.

Now that the great Naaman has washed in the supposedly small river in Israel and got healed, one should resist the temptation to exalt the rivers of Israel over those of Aram. The story does not make or encourage contrasts. Naaman correctly ascribes his healing to the LORD rather than to the river Jordan (v. 15). While the LORD is universal, the river Jordan will always remain in Israel. This is the same God to whom the greatness of Aram, if it were to be understood as greatness, should be ascribed. The LORD is the equaliser of the relationship between Aram and Israel and evens out Israel's and Aram's purported greatness. The national level at which Naaman sought to differentiate between Aram and Israel has been neutralised by the river Jordan's cure of his

39 Cohn, "Form and Perspective," 176.

40 Cohn, "Form and Perspective,” 178. 
leprosy. Furthermore, when he spreads the soil to make an altar for the LORD in Aram, he will be reminded that the soil in Israel is not inferior to the soil in Aram (v. 17). At a personal level, Naaman has made himself small by coming to stand before (עמד לפני) Elisha (v. 15). It is a term of submission that Elisha uses when he comes before the LORD (v. 16). Then Naaman goes on to call himself Elisha's servant (עבדך) four times (in vv. 17 and 18). From the story, his confession, "There is no God in all the earth but in Israel” (v. 15), is true and symbolic of his baptism in Israel, regardless of the extent of his sincerity.

\section{GEHAZI SYMBOLICALLY ACQUIRES NAAMAN'S GREATNESS}

By the end of the narrative, Gehazi has swapped places with Naaman. The rhetoric of the story comes out strongly here. Naaman's position is diseased altogether with its power and wealth. In v. 1, we find the man amplified extremely in greatness but having a serious problem. In the process of cleaning Naaman of leprosy, it also cleans him of his perverse greatness and dilutes Aram's superiority over Israel. After the prophet of God refused the riches of Aram, his servant (נער) Gehazi runs after them. He swears that, "As surely as the LORD lives, I will run after him and get something from him” (v. 20). One notes that Gehazi swears to get "something," which is so general it could range from useless to dangerous. Consequently, the audience has to conclude that whatever Gehazi receives, he will deserve it. In any case, Gehazi is thinking about the gifts that his master had refused. His vow is like Elisha's in v. 16, but there were two differences with Elisha's, namely: Elisha had added "before whom I stand," meaning that he honoured the LORD. Furthermore, Elisha was swearing to refuse the gifts of wealth from Naaman. In contrast, Gehazi omits "before whom I stand ..." in his vow and then swears to take what Elisha has refused (v. 16). The omitted words are those of submission, indicating his lack of submission, unlike his master, Elisha. Gehazi's attitude was of greed (v. 20) and deceit (lying to Naaman and to Elisha and hiding the goods; vv. 22, 24 and 25).

Moreover, as he runs to take Naaman's position, he belittles him with the expression "this Aramean" (v. 20). ${ }^{41}$ Naaman climbs down from his chariot when he sees Gehazi approaching. The word used for Naaman's act is fall (נפל), albeit with the doubled preposition "from on" (מעל; v. 21). It is a remarkable act of humility that he makes himself "fall down" not for the prophet but the servant. Gehazi is symbolically exchanging positions with Naaman as Naaman humbles himself. Then Gehazi acquires wealth from Naaman and Gehazi commences to make his servants carry the loot before him (לפני) as he walks majestically behind them. ${ }^{42}$ This is reminiscent of how God's servants stand before God and insignificant people stand before their superiors;

41 Wiseman, 1 and 2 Kings, 208.

42 Kim, "Reading and Retelling," 58; Sweeney, I \& II Kings, 301. 
He causes the servants to perform the humbling לפני that he himself omitted to acknowledge a few moments earlier. He has become great. Whilst Naaman arrived as a great man and departed as a humble servant, Gehazi arrived as a servant but departed as a master. Furthermore, Naaman arrived with wealth, lost some of it to Gehazi but departed with the fear of the LORD. Gehazi started without wealth, took Naaman's wealth, started in the presence of God but left without the fear of the LORD.

\section{J ELISHA REBUKES COLONIAL IDEOLOGY}

Naaman's indebtedness cost him his greatness in the presence of Elisha as he humbled himself before Elisha. By giving him back the opportunity to pay that debt, Gehazi granted Naaman a chance to drift guilt-free back to his old life. ${ }^{43}$ Better still, everything turned out much cheaper than Naaman originally thought. ${ }^{44}$ We are left wondering what will happen to Naaman's psyche. As for Gehazi, he now embodies the ideology represented by Aram and Naaman when the story started. Elisha rebukes Gehazi with the question, "Is this the time to take money, or to accept clothes, or olive groves, vineyards, flocks, herds, or menservants and maidservants?” (v. 26). In this rebuke, Elisha has summarised the principal attitude behind colonialism - to enrich oneself, to loot and impoverish the conquered and to declare oneself superior while turning others into servants. This is a perfect rebuttal of the mentality which Elisha knew had corrupted the attitudes of the Arameans and made life difficult for the conquered Israelites. From this rebuke, it seems that Elisha would not like Israel to do the same to Aram. By paying the prophet, Naaman takes credit for the riches that he owns as if they are really his. Yet they are probably stolen goods looted from weaker nations. Naaman's job as an army general, and by extension, his greatness, only exist because he murders, enslaves, loots and destroys defenseless innocent nations. It is not the kind of greatness Naaman should be proud of.

Probably, Elisha was also aware of the attitude that regarded Israel as superior to Aram in other forms such as healing rivers and the omnipotent God of Israel. Gehazi represented some Israelites who might want to take credit for and exploit such forms of greatness. If Gehazi gives in to the temptation to take advantage of vulnerable foreigners, then he too embodies the vicious cycle of looting that Naaman thrives on. From the discourse of the story, Naaman's and Gehazi's version of greatness is diseased. To claim it is to gain leprosy, but to lose it is to lose leprosy. Thus, at the climax of the story, Gehazi goes out from before (מלפני) Elisha a rich leper (v. 27). He completes the acquisition of the colonial-style greatness that Naaman brought with him.

\footnotetext{
43 Sweeney, I \& II Kings, 301.

44 Brueggemann, "Perpetual Shalom,” 33.
} 
416 Berman, “Greatness versus Smallness,” OTE 29/3 (2016): 403-418

\section{K THE CORRECT ATTITUDE IN THE POSTCOLONIAL ERA}

The story of the healing of Naaman is a lesson for how we ought to live in the present world. Firstly, the stronger nations should not revel in the dichotomy of "greatness versus smallness." Instead, they should live in gratitude to the God who made them successful. Colonial mentality should be combatted so that none of us exalts ourselves over the other. For example, for a long time some individuals have clung to notions of racial superiority as if they had chosen to be born white, to be born in a richer country, or to be born in Europe. Even the cliché black is beautiful should not be cited to claim that black skin is superior to white skin. The proper attitude should be that our being born black or white, rich or poor, western or two-thirds world is an act of God. As Elisha teaches Gehazi, we should not desire to swap positions with oppressors because we too would turn into oppressors.

Secondly, as fellow human beings, we often need one another for different reasons. The great Naaman has come to a point where his help can only come from a nation that is supposedly weaker than his and from people whom he regards as socially inferior to him. Starting with the little maidservant and through Elisha and Naaman's servants, Naaman learns the way towards healing. The narrative could teach us to value everyone regardless of their race or colour and whether they are coloniser, colonised, servant or master because there could be times when they will be our only means of salvation. Thirdly, relating to Naaman's regard for the River Jordan and the soil of Israel, we can be reminded to cherish natural resources across borders. Contemporarily, this is not a difficult call because probably every country has tourists who occasionally or habitually visit other countries to view and admire natural resources. In the beginning, Naaman belittled the Jordan river but later cherished it, including the soil of Israel. Not only do they give pleasure to human viewers, but the survival of natural resources can help balance the eco-system and benefit animals, vegetation and people even more.

Fourthly and lastly, a postcolonial mindset searches for ways to learn religious tolerance. Since history records many atrocities committed in favour of or against Judaism, Christianity and Islam, we should tolerate each other's religious preferences. This call is especially important when one fails to convince the other to convert to one's religion, be it Islam, Christianity or Judaism. Both Naaman and Elisha appraise each other's religious preferences without giving advice or challenging them. Elisha did not comment on Naaman's level of gratitude to the LORD, even where he would have been justified. He dismissed him with a blessing even while knowing that he will continue worshipping as he used to. 


\section{CONCLUSION}

The narrative presents to us a diseased form of greatness. Naaman and Aram are the conquerors of Israel. The problem with this greatness is that it is possible only at the expense of the other party. We find this inequality reflected in the relationships between Aram's armies against Israel, Naaman against the little maidservant, Naaman against Elisha, the rivers of Aram against those of Israel, and the king of Aram against the king of Israel. At the end, the narrative manages to symbolically balance the relationship and deliver a rebuke by the use of the character of Gehazi. Gehazi has symbolically swapped positions with Naaman in terms of power, wealth, health and service to the LORD. Elisha's mindset is a fitting conclusion to this postcolonial analysis. In a relationship of inequality, focus must be shifted away from the concept of "greatness versus smallness."”

\section{BIBLIOGRAPHY}

Austel, Hermann J. and Richard D. Patterson. “2 Kings.” Pages 537-583 in Old Testament. Volume 1 of Zondervan NIV Bible Commentary: An Abridgment of the Expository Bible Commentary. Grand Rapids, Mich.: Zondervan, 1994.

Baeq, Daniel S. "Contextualizing Religious Form and Meaning: A Missiological Interpretation of Naaman's Petitions (2 Kings 5:15-19).” International Journal of Frontier Missiology 27 (2010): 197-207.

Bowman, Richard G. "Narrative Criticism: Human Purpose in Conflict with Divine Presence.” Pages 10-33 in Judges and Method: New Approaches in Biblical Studies. Edited by Gale A. Yee. Minneapolis: Fortress Press, 1995.

Brueggemann, Walter. "Perpetual Shalom: Elisha’s Gift to Naaman.” Christian Century (2012): 30-33.

Cohn, Robert L. "Form and Perspective in 2 Kings V.” Vetus Testamentum 33 (1983): 171-184.

Farrar, Frederic W. “2 Kings.” No Pages in The Expositor's Bible Commentary: With the New International Version. Edited by Frank E. Gaebelein. Grand Rapids: Zondervan. Cited 22 September 2016, http://biblehub.com /commentaries/expositors/2_kings/5.html.

Gotom, Musa. “1 and 2 Kings.” Pages 409-466 in Africa Bible Commentary. Edited by Tokunboh Adeyemo. Grand Rapids, Mich.: Zondervan, 2006.

Jasper, David. “Literary Readings of the Bible.” Pages 21-34 in The Cambridge Companion to Biblical Interpretation. Edited by John Barton. Cambridge: University Press, 1998.

Keil, Karl F. "2 Kings.” No Pages in Commentary Critical and Explanatory on the Whole Bible. Edited by Robert Jamieson, Andrew R. Fausset and David Brown. Grand Rapids, Michigan: Zondervan. Cited 22 September 2016, http: //www.biblestudytools.com/commentaries/jamieson-fausset-brown/2-kings/2kings-5.html.

Keil, Karl F. and Franz Delitzsch. 2 Kings. Biblical Commentary on the Old Testament. T\&T Clark Edinburgh, 1857-1878, http://biblehub.com/commentaries/kad/2_kings/5.htm 
Kim, Jean K. “Reading and Retelling Naaman’s Story (2 Kings 5).” Journal for the Study of the Old Testament 30 (2005): 49-61.

Konkel, August H. 1 \& 2 Kings. The NIV Application Commentary. Grand Rapids, Mich.: Zondervan, 2006.

Maeir III, Walter A. "The Healing of Naaman in Missiological Perspective.” Concordia Theological Quarterly 61 (1997): 177-196.

Malbon, Elizabeth S. "Narrative Criticism: How Does the Story Mean?” Pages 23-49 in Mark and Method: New Approaches In Biblical Studies. Edited by Janice C. Anderson and Stephen D. Moore, eds. Minneapolis: Fortress Press, 1992.

Nwaoru, Emmanuel O. "The Story of Naaman (2 Kings 5:1-19): Implications for Mission Today.” Swedish Missiological Themes 96 (2008): 27-41.

Powell, Mark A. "Literary and Stucturalist/Postmodernist Approaches Methods." Pages 169-172 in Methods of Biblical Interpretation. Edited by David Knight. Nashville: Abingdon, 2004.

Pui-Lan, Kwok. "Making the Connections: Postcolonial Studies and Feminist Biblical Interpretation.” Pages 45-63 in The Postcolonial Biblical Reader. Malden: Blackwell Publishing, 2006.

Sweeney, Marvin A. I \& II Kings: A Commentary. Louisville: Westminster John Knox Press, 2007.

Tate, Randolph W. Biblical Interpretation: An Integrated Approach. 3rd ed. Grand Rapids, Mich.: Baker Academic, 2012.

Wren, Brian. What Language Shall I Borrow? God-talk in Worship: A Male Response to Feminist Theology. London: SCM Press, 1989.

Wiseman, Donald J. Tyndale Old Testament Commentaries: 1 and 2 Kings. Leicester: Inter Varsity Press, 1993.

Yorke, Gosnell. Bible Translation in Anglophone Africa and Her Diaspora: A Postcolonial Agenda. London: Equinox Publishing Ltd, 2004.

Dr. Sidney K Berman, North West University, Private Bag X2046, Mmabatho, 2735. Email: sidneybrmn@yahoo.co.uk. 